\title{
Strategy of Actors SMES during COVID-19 in Strengthening Regional Economy
}

\author{
Khairuna $^{1}$, Asnariza ${ }^{2}$, Rahmah Yulianti ${ }^{3}$ \\ ${ }^{1,2,3}$ Faculty of Economics, Department of Accounting, Universitas Serambi Mekkah \\ Banda Aceh, Indonesia
}

Corresponding Author: Khairuna@serambimekkah.ac.id

\begin{abstract}
This study aims to examine strategies for SMEs actors during COVID-19. COVID-19 has had impacts on various sectors, especially in economic sector. COVID-19 in Banda Aceh has effect not only in health sector but also in education sector and in economic sector (in their business sectors especially for SMEs). Because of the reason a strategy is needed to maintain SMEs business in the midst of this pandemic. This research was conducted during the COVID-19 pandemic in the period from March to December 2020. The research method used in this study is a qualitative analysis with applying an exploratory step and with participatory observation techniques. The analytical method used is a descriptive approach that identifies various problems faced by SMEs, analyzes the problems, and formulates a strategy model to overcome the problems. Result of this study recommends a strategy for SMEs in adapting any changes that occur through a new strategy to support development of local SMEs. The development strategy is analyzing the strategy by using SWOT analysis. The analysis relies on technology to reach consumers and adjust consumers' condition to sale of products and services. The survival strategy is implementing ECommerce, digital marketing, product quality improvement, service quality improvement, and Customer Relations Marketing (CRM).The results of this study are important to be understood and adopted by SMEs and it is hoped that SME actors will always be responsive to adapt to environmental changes so that they still enable to survive and also still strengthen regional economy and then experience growth.
\end{abstract}

Keywords: SME Strategy, Strengthening regional economy, COVID-19

\section{Introduction}

SME (Small and Medium Enterprise) is a type of business founded by a person with maximum wealth about Rp. 200,000,00.00 not including land and buildings. (Akifa P. Nayla, " Complete Accounting In general, definition of SME is a business that produces goods and services using whose natural and human resources utilized traditionally and the resources come local area for SMEs and Franchising" (Laksana, 2014).

SMEs are required to be able to adapt to business developments because surviving business is responsive to any kind of situations. SMEs should adapt to any changes that occur through a new strategy aimed to support local business development. One way to adapt to the changes is to rely on technology to fulfill consumers' interest and must adjust to condition of products and services' sales (Wan and Laura, 2020).

There are three basic problems of SMEs, namely: capital, product quality, and product marketing. In terms of capital, the Banda Aceh City Government has collaborated with Sharia Microfinance institutions to support SME. Sharia Microfinance institution is a financial 
management system that uses the principles and basics of Islamic law as a guideline. In terms of product quality, the Government tries to provide packaging services, to adjust service that enable to attract consumers' interest. Business parties should build trust and good relations with consumers or relationship marketing, because there is still lack of understanding in applying SMEs' relationship marketing. In terms of production marketing, the government has also made efforts to introduce SME products locally, nationally, and internationally (Firdaus, 2021).

The urgency of this research comes from global spread of the COVID-19, which has an impact on economic sector in Banda Aceh, especially growth of SMEs which is very susceptible to being affected by business interference. For the reason, the Office of Medium, Small, and Micro Enterprises Banda Aceh has conducted various programs through Forum Group Discussion to promote development of SMEs. This research can also be used as a reference for SME by describing and implementing survival strategies for SME so that they are still able to survive and become more responsive to business climate change, especially during the COVID-19.

Data from the Office of Medium, Small, and Micro Enterprises of Banda Aceh shows that there were 10.944 SMEs in 2018, 12.012 SMEs in 2019 and 15.107 SMEs in 2020. Banda Aceh is dominated by SMEs which are backbone to strengthen regional economy. Number of SMEs from 2018-2020 continues to grow. This is due to large number of job changes due to several companies reducing employees so that employees open SME businesses. SMEs has lack resilience and flexibility in dealing with this pandemic due to several things such as low mastery level of digitalization, difficulties in accessing technology, and lack of understanding about strategies to survive in business (OECD, 2020).

Regarding the COVID-19 pandemic, there are regulations from the Government requiring public to stay at home unless in urgency conditions. This also has an impact on limited operation of SMEs and decrease number of consumers who shop offline. Because of the situation, business parties adjust their sales by selling through e-commerce. E-commerce is a selling, purchasing, and marketing selling products by utilizing electronics (Kotler, Philip, and Armstrong, 2012). Research by Hardilawati 2019b and Setyorini et al 2019 concluded that e-commerce has a positive and significant influence on improving marketing performance and income of SMEs.

In addition to conduct e-commerce, SMEs are also required to be able to promote products intensively by marketing products digitally, and utilizing social media to reach consumers directly and to reduce promotional costs. Digital marketing is marketing using internet access, utilizing social media, and other digital devices. Digital Marketing helps companies in promoting and marketing their products and services and being able to expand business without limitation of time, distance, and communication (Prabowo, 2018). Results of the study conducted by Hendawan et al., 2019) state that digital marketing has a positive and significant effect on increasing SME sales.

The COVID-19 pandemic has caused a shift and change in consumer buying patterns. Even though there are online sales, many consumers still prefer to buy products directly in stores or shopping centers. SMEs also have to improve product quality and service adjustments to attract consumers' interest. The decline in sales and consumers' trust is also very influential on the SMEs business thus SMEs business needs to build trust and good relations with consumers or relationship marketing. Relationship marketing is a business orientation that focuses on maintaining good relationships with customers and building close and mutually beneficial relationships between sellers and consumers to create repeat transactions to form loyal consumer (Kotler, Philip, and Armstrong, 2012). 
Competitiveness can be created or enhanced by implementing appropriate competitive strategies, one of which is by managing resources effectively and efficiently. In addition, determination of proper strategy must be adapted to all business activities, so that it will improve company's performance as expected and finally can generate value. All companies, especially SMEs compete to be at the forefront in the era of competition. Therefore, every $\mathrm{SME}$ is required to have high competitiveness, so they must begin to improve themselves. SMEs that have high competitiveness are characterized by reliable human resource (HR) capabilities, high knowledge domination, and economic domination.

Furthermore, according to Rahmana (2009), SMEs should apply information and technology to increase their competitiveness in globalization era because growing global competitiveness. Utilizing Information and Technology will encourage SMEs to get export opportunities and other business opportunities. SMEs development activities should directly conduct competitiveness analysis and formalize efforts to increase competitiveness and then increase national economy. Sharpening improvement of business competitiveness is in line with future business competition. Indonesia, a large and growing population country, urgently needs strong and competitive SMEs in the domestic and global markets. SMEs are key to improve quality of national economy. It needs several regulations which is supported by all stakeholders, to approve domestic market as basis market for developing SMEs.

Based on the description above, research questions in this research are strategies used to develop SMEs and to strengthen SMEs thus SMEs can reinforce national economy. Objectives of this research are:

1. To formulate development and surviving strategies of SMEs in strengthening regional economy.

2. To find out, describe, and analyze government's role in development and survival of SMEs.

Benefits of this research are divided into two benefits, namely theoretical and practical. Theoretical benefit is expected to contribute as an additional reference for students and other researchers on science and insight about development and survival strategy of SMEs. Results of this study are expected to be used as comparative information to previous researchers and will become reference for further researchers who will conduct on same research topic. And practical benefits the results of this study are expected to provide input for local governments in developing and finding solutions to solving problems of Micro, Small and Medium Enterprises (MSMEs). For researchers themselves, it serves as a means or vehicle for researchers to expand their knowledge and experience so that they can add insight in practical thinking.

SME (Small and Medium Enterprise) is a type of business founded by a person with maximum wealth about Rp. 200,000,00.00 not including land and buildings. (Akifa P. Nayla, "Complete Accounting for SMEs and Franchising", (Laksana, 2014:12). In general, definition of SME is a business that produces goods and services using whose natural andhuman resources utilized traditionally and the resources come local areas.

\section{Small and Medium Enterprises (SME) Development Strategy}

Development is an effort made to promote, sharpen, and improve, improve something that already exists regularly and gradually to make it better. SWOT analysis is a strategic planning method that implemented to evaluate strengths, weaknesses, opportunities, and threats of a company. This process includes determining specific objectives of business speculation and identifying internal and external factors that support and do not encourage these goals. SWOT analysis is useful for analyzing internal factors in the organization that 
contribute to service quality or one of its components while considering external factors. The strategic decision-making process is always related to development of the organization's mission, goals, strategies, and policies. Thus, strategic planner must analyze organization's current strategic factors (strengths, weaknesses, opportunities and threats).

1. Strengths: characteristics of a business, or project that give advantage over competitors.

2. Weaknesses: are characteristics that place the business/project at a disadvantage compared to others.

3. Opportunities: external opportunities to improve performance (e.g make higher profits) of the organization.

4. Threats: external elements of the organization that can cause problems for the business or project.

In a process of developing Small and Medium Enterprises (SMEs), the first step to be fulfilled is to identify problems, in order to determine the proper strategy. The development strategy relates to the methods or procedures used to achieve goals effectively and efficiently.

\section{SMEs Development}

Development, defined as an effort to improve conceptual skills and theo-training, stated that development of SMEs is more directed to become competitive parties in economy through strengthening entrepreneurship and increasing productivity supported by efforts to adapt to market interests, to utilize innovation and to apply information and technology (Afifuddin, 2010:180). Influence of development of SMEs in Indonesia and role of the government in increasing growth of SMEs in Indonesia have positive results, both directly and indirectly. (Tambunan, 2009:04).

The development of SMEs is essentially a shared responsibility between government and related parties. After observing the problems faced by SMEs, efforts needed consist of: (a) creating a conducive business climate, (b) capital assistance, (c) business protection, (d) partnership development, (e) training, (f) developing promotions, and (g) developing equal cooperation. (Hafsah 2004:43-44).

\section{Survival Strategy for SMEs}

There are several things that SMEs can do to survive such as responsive to changes in their business environment (Wan, Laura, 2020: 92). The strategies that SMEs can do are as follows:

1. E-Commerce

E-commerce is a process of buying and selling products (business transaction) electronically by and from a company to another (Laudon \& Traver, 2016). Through ecommerce, product sales barriers in terms of sales range can be eliminated. SMEs participants can take advantage the eliminated range to expand market share and build relationships using an optimal marketing system. Several e-commerce platforms that can be utilized by SME in Indonesia such as shopee, tokopedia, bukalapak, OLX, gojek, lazada, etc.

2. Digital Marketing

Digital marketing is an promotion activity and market search digitallyby using various tools, for example social networking (Purwana et al., 2017). In order to market more effectively, SMEs need to always update and adapt to new technology. Media sosial should be used selectively and communication should be determined properly in order to adapt to market share. 
Digital marketing tools which are often used by business partiesto market products are Instagram, Facebook, Twitter, and et cetera. Rapid technological developments must be comprehend and learnt by both for consumers and SMEs.

3. Product and Service Quality Improvement

Product quality is defined as ability of a product to meet consumer needs and desires (Kotler, Philip and Armstrong, 2012). Therefore, SMEs need to periodically improve product quality by adjusting the needs, desires and expectations of consumers.

Applied product quality improvement is to carry out more detailed product quality control and to ensure product cleanliness and safety. In addition, SMEs adjust product and packaging resilience because current sales use online sales more often so that product durability and safety also must be improved.

In addition to improve product quality, SMEs also improve service quality and add some types of services such as delivery orders, online purchasing services, and hotline service that can be easily accessed by consumers.

4. Customer Relationship Marketing (CRM)

Customer relationship marketing is a marketing strategy concept that seeks to establish long-term relationships with consumers, namely maintaining a strong and mutually beneficial relationship between service providers and consumers so that consumers can repeat buying transactions and increase their loyalty. Consumer loyalty can be achieved when consumers are satisfied and SMEscan maintain their relationships with consumers.

\section{Regional economy}

Regional economy can be understood from two approaches,first, approach to smallscale economic activities (people's economy). People's economic empowerment is intended to empower small-scale economic business. Second, economic democracy or democratic development system (participatory development). Economic empowerment of people in this approach is intended to apply principles of democracy in developing. This means that the people's economy is an economic system that involves whole citizens in development process as development drivers. Thus, this second approach is also referred to as a people's economy or a people's economic system (AZ Yasin, 2002).

There are several things that must be considered in the economic system that leads to a people's economy, namely: (1) regional characteristics and expertise background of local citizens majority, (2) people-based economy, namely economic activities that are in accordance with expertise oflocal citizen majority, (3) regional characteristics, namely increasing value of regional potential, (4) role of local governments, namely encouraging growth of the people's economy through improving facilities and infrastructure so that the people's economy grows and develops rapidly, (5) local potential/ SMEs, namely encouraging growth of potential-based SMEs by empowering formation of cooperatives or productive units. (Zulkarnain, 2003: 98).

\section{FRAMEWORK}

According to Sugiono (2011: 60) thinking of framework of this research is a conceptual model of how a theory relates to various important factors that have been identified, so that the framework is an understandable theory that support other understandings, the most basic theory and becomes rationale for every thought or process of the whole research procedure. 


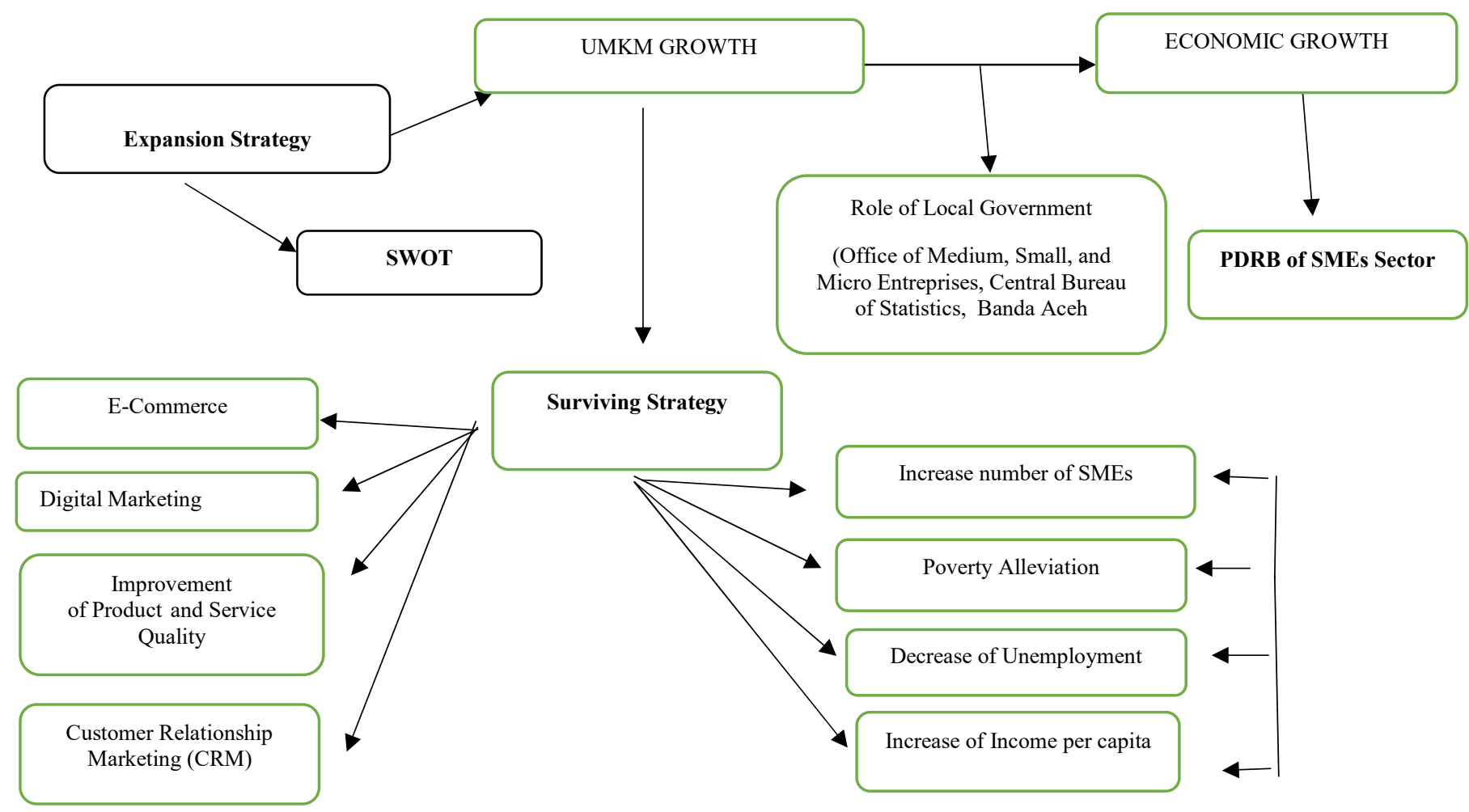

Figure 1.1 Thinking Framework

\section{Method}

This research is a qualitative method. According to (Semiawan, 2010), qualitative research methods are the most appropriate type of research method in capturing, recognizing, and understanding something or human perceptions only with direct contact, with an open mind, and through inductive processes and symbolic human interactions humans. This research was conducted in Banda Aceh city and uses SMEs as object of research. Data collection technique used in this study was participatory observation with an exploratory step, namely conducting data sources. One of the qualitative data collection techniques used was primary data through observations and secondary data through data collected, processed and presented by other parties such as books and SMEs previous researches. This research's findings and issue recommendations can be adopted by SMEs. The other data sources consist of interviews to Office of Medium, Small, and Micro Entreprises (UMKM) and Central Bureau of Statistics (BPS), data obtained from relevant websites, journals, and articles. Data collection techniques used in this study are observation, interviews, and documentation.

\section{Result \& Discussion}

At the end of 2019, COVID-19 emerged so that global economy fell due to the implementation of the lockdown. Facing this crisis situation, Banda Aceh government does not rule out SMEs vital role in driving local economy. The Government distributes capital assistance SMEs affected by COVID-19 who have not received any assistance from the government yet. The government also provides opportunities and empowers SMEs to produce products. 
Based on latest data on 15 October 2020, in Banda Aceh there were 1,870 cases of COVID-19 ( https://COVID19.acehprov.go.id/. With the appeal and policy of Banda Aceh mayor, only enterprises especially SMEs in food processing, open from 08.30 to 23.00 WIB, so that there are no crowds in the food and beverage stores or cafes in Banda Aceh, and the policy of course affects many things, including SMEs.

According to the Office of Cooperatives, Medium, Small, Micro Entreprises and Trade (DISKOPUKMDAG) of Banda Aceh, 2017-2020 strategic plan (rencana strategis), there are several problems have to be fixed, namely:

1. Low investment in Banda Aceh,

2. Market does not run optimally and street vendors are not discipline

3. No optimal supervision of goods and services circulation

4. Not optimal implementation of repeated activities

5. Limited development of Small and Medium Enterprises and Cooperatives.

6. Low human resources engaging in cooperative and SMEs

7. Lack of application of recent technology

8. Lack of entrepreneurial skill

9. Lack of valid SMEs data

10. Low awareness of traders to occupy a predetermined market

11. Lack of HR in market management.

Based on the results of an interview with the Head of Cooperatives, Medium, Small, Micro Entreprises and Trade of Banda Aceh, generally and recently, there are no SMEs that have an impact on the COVID-19 pandemic, unless at the beginning of the COVID-19 pandemic from March to September 2020. There are several indications of the impact of the COVID-19 pandemic on SMEs, namely decline in number of purchasing due to decrease in outside home activities and decline of public trust in circulated products, especially food and beverage products that are induced to the most decrease profits during the COVID-19. In addition, there are obstacles in distributing goods and services from producers to consumers, in which SMEs have difficulty in obtaining raw materials due to transportation constraints. Strategy for SMEs to maintain their business is to continue to innovate, to improve product/service quality standards and to provide online delivery services optimally. The government also helps SMEs by conducting group discussion forums (GDF) and providing assistance such as equipment and a number of funds to SMEs. To take advantage of online sales, SMEs have to adjust to the business, such as business fashion temporarily diverted to a fast food establishment, because food industry businesses give contribution to local economic growth of the region, handy craft businesses switch to create products of a mask with Aceh pattern, conduct herbal or traditional medicine businesses, make hand sanitizers, so that SMEs can survive and adapt to the conditions of the pandemic. In recent years, SMEs in Banda Aceh have increased and the trade and industry sectors are the largest business sectors.

There are several development strategies that can be done by SMEs. One of the processes of determining strategy in marketing is analyzing the situation, and the most famous tool in situation analysis is SWOT analysis. SWOT Analysis is the process of identifying which ( strength), weakness ( Weakness ), opportunity ( opportunity) and threats ( threats ) organization (Quesenberry, 2019). Previous research conducted by Firdaus (2021) entitled analyzes social media marketing strategies on micro small and medium enterprises 
(SMEs) in the city of Banda Aceh. The study revealed that social media is an effective marketing tool for MSMEs in the city of Banda Aceh in the trade sector. The most effective social media are Instagram, WhatsApp, and followed by Facebook and the results of the quantitative SWOT analysis on MSMEs in Banda Aceh City in the trade sector are in quadrant I, namely aggressive strategy. The implications of this research are useful references and inputs for MSME actors in the city of Banda Aceh in the trade sector to find out the factors that influence internal and external as well as how to implement effective and efficient marketing strategies through social media.

Internal Strength Factor (Strengths) consist of the first is Design, Strength that distinguish between enterprises of the effort the other is an ad that was so interesting and characteristic that attracted the attention of potential consumers who see their ads; Consistent Update Information, SMEs must try to always post new advertisements or update posting information on social media at least once every two days so that followers and companies stay connected to each other; SME Discount Offers provide discounts or promos at least once a month to their consumers in order to maintain the loyalty of old customers and attract new customers; The latter have a Marketing Team, SMEs must have a marketing team to create content and advertisements. The marketing team consists of designers, copywriters and photographers. Having a marketing team will make it easier to divide tasks, so owners can focus on other things.

Internal Weaknesses Factors ( Weaknesses ) consist of Haven't tried the live feature on Instagram and Facebook Currently, there are many sellers who meet on social media doing live on social media. Live streaming can be used to interact directly with potential buyers. Live streaming can also have a big enough influence to build engagement directly. In general, there are still many SMEs that have not used the live features on social media; Low Quality of Customer Service, The importance of quality customer service. When potential consumers are interested in the products offered by the seller, then the prospective buyers will ask about the product they want to buy whether it is in accordance with the price and specifications of the desired product. Answering a lot of questions through social media will take a lot of time, especially if potential customers do not buy.

Factors of External Opportunities consist of The Use of Social Media is Very Much and Trending. SMEs use social media because there are so many social media users that it provides product marketing opportunities. Millennials currently use social media to share image and video content so they can stay connected with their friends and relatives. Situations like this are beneficial for marketers because apart from social media, many users are also trending among the public as a means of communication; Easily Reach Consumers Marketing through social media can reach consumers more easily because marketers can make marketing communications or interactions through social media tools without having to meet with consumers; The latter Social Media Advertising Is Relatively Cheaper, In general, SMEs in their early stages of building a business, they promote their products through social media. Social media offers features to share photos or videos for free. In addition, Instagram and Facebook also offer premium ads that can target consumers specifically based on age, demographics, and user interests on Facebook. These premium features are relatively cheap starting from Rp. 30,000 per day.

External Threat Factors (Threats) consist of Easy to Imitate Products, As a result, they often do a lot of advertising on social media, allowing anyone to see the products or offers they offer so that people can easily imitate these products and sell them cheaper; Application of Facebook and Instagram Taxes. For SMEs that have used paid advertising on Instagram and Facebook, they can target ads based on gender, age, and 
demographics. Starting September 1, 2020, regardless of the purpose of advertising whether for personal or business, Facebook and Instagram will impose a tax (VAT) of 10 percent; The latter Prospective Buyers Lack of Trust in Social Media Social media as a marketing tool that is easy to offer products or services to the public without having to have a physical store. This has resulted in some potential consumers not believing in the product or service offerings offered through social media.

Another finding based on observations, not all MSMEs felt a decrease in sales turnover and had to close their business, there were MSMEs that were still stable and experienced an increase in sales turnover because they made adjustments in terms of products and carried out several marketing strategies to survive. Previous research conducted by Wan Laura (20 $20: 89-98$ ) entitled MSME Survival Strategy in the Midst of the COVID-19 Pandemic. The research revealed that survival strategies for SMEs and SMEs are in the form of e-commerce trading, digital marketing, improving product quality and adding services as well as establishing and optimizing customer marketing relationships.

There are several things that can be done by MSMEs including choosing to open new product lines or updating their marketing system, because businesses that are able to survive are businesses that are responsive to changes in their environment. There are several things that can be done by SMEs are as follows:

\section{E-Commerce}

Sales directly generally decreased during the pandemic COVID-19 because the pattern of society to remain at home. In addition, the Banda Aceh City Government Regulation regards restrictions on operating hours. One way to keep running a business and reach more consumers and expand market share that can be done by MSMEs is to expand their network by utilizing e-commerce sales. E-commerce is a process of buying and selling products electronically by consumers and from company to company with computers as learning media.

The main purpose of using e-commerce by MSME actors is of course to be able to increase their profits, but besides that there are other goals that can be utilized by business actors including being able to reach a wider market share which was previously limited to selling only in certain areas, by The existence of e-commerce can reach new consumers. MSME actors can not only make e-commerce a selling portal, but can build relationships and build new market concepts and use a more effective marketing system and make e-commerce also a learning medium. MSME actors can also see and observe sales made by competitors and adopt them.

\section{Digital Marketing}

Some of the challenges of MSMEs during the COVID-19 pandemic have greatly reduced SME sales turnover. The reduced number of consumers in several sectors and industries requires MSME actors to be able to market their products optimally and think creatively and innovatively. One of them is the use of the internet, which during the COVID19 pandemic has become like a necessity, including running a business and one of the efforts in cooking products that can be adopted by MSMEs is to do digital marketing. Today's rapidly developing digital era is impossible to avoid. Marketing expert Yuswohadi revealed that if they want to survive, MSME actors must be able to maximize the benefits of digital development (Purwana et al., 2017).

Digital marketing is a promotional activity and market search through digital media online by utilizing various means, such as social networks (Purwana et al., 2017). The digital marketing method that is often used by business actors is to use social media such as marketing products through social media. In addition, digital marketing can also be done on 
e-commerce and many other media. Rapid technological developments also make digital marketing must be understood and studied by MSMEs. Of course, digital marketing also considers using suitable media and the right way of communication that is tailored to the selected segment or market share. So that marketing will be more effective and not misdirected.

SMEs can do marketing of products with some form of digital marketing that can be done is as follows: (1) Publication of videos and photos of the product in an intensive social media accounts. The use of social media is also adjusted to the product segments that we have. (2) Utilizing facebook ads, instagram ads, twitter ads, google display networks, etc. which can be easily accessed through social media and can reach consumers with the criteria that we have previously determined. (3) Making marketing product videos that are shown through social media or doing live product promotions. This strategy if done correctly will have a positive effect on the business. (4) Involving consumers in product selection, conducting education and introduction to product quality intensively on social media accounts and using creative words and using hashtags (\#) to make it easier for consumers to find them. With this, brand awareness will be formed and can influence consumer purchasing decisions. (5) involving celebgrams and social media influencers to help promote the business products/services of MSME actors.

\section{Product and Service Quality Improvement}

COVID-19 pandemic causes decrease in consumer trust in goods and services sold by business parties. In addition, the limitations of consumers to purchase directly also have an impact on a significant decrease number of consumer buying. For this reason, SMEs must improve their product quality to increase consumer trust and intensively advertiseproduct quality. Product quality improvement that can be done is to carry out more detailed product quality control and to ensure product cleanliness and safety. In addition, SMEs can adjust their product and packaging resilience because online sales more often used so that product durability and safety must be further improved.

In addition to improve product quality, SMEs can also improve service quality and add different types of services such as online delivery and purchase services and use a special hotline sales service that can be easily accessed by consumers. Although there are businesses that cannot open directly, SMEs can deliver their product directly, such as deliver product by using applications such as Gojek, Grab, etc. In carrying out delivery services, SMEs also tighten their service standards by improving and ensuring cleanliness of their products. For services, services can be developed through online media and using online service activities so that they can be more effective and business can run as usual. A good product will be able to create consumer trust so that it leadsto customer satisfaction and form consumer loyalty. During this pandemic, consumer trust is an important factor in business sustainability.

\section{Customer Relationship Marketing (CRM)}

During the Pandemic period, SMEs should not only focus on attracting new customers but also must maintain quality products and maintain existing customers, create customer satisfaction and create customer loyalty. Loyal customers will not switch to another sellers because they already have trust in the sellers' products. One way for SMEs to survive in the midst of decline business is by doing customer relationship marketing. Customer relationship marketing is a marketing strategy that establishs a long term relationship with the customer, ie maintain a solid relationship and mutual benefit between sellers and customersthat can create repeat transactions and customer loyalty. 
Currently, to establish marketing relationships with customers, SMEs are also advised to be able to concern more about their consumers who are experiencing difficulties during the pandemic. SMEs can show concern that is also aimed to market product, such as providing promotions or free product schemes for couriers who provide delivery services,setting aside a portion of their incomes for people in need. This method can also build consumer trust and bonding. SMEs do not also think about profits, but also do positive things such as building consumer marketing relationships by showing concern to their consumers. In addition, SMEs can create positive customer engagement and communicate with customers in various promotional media and intensively utilizing e-commerce, such as answering sales complaints or responding to good responses from consumers, and giving giveaways for loyal consumers.

\section{Conclusion and Suggestion}

Based on results of this research, it can be concluded as in the following. COVID-19 occurred in early 2020 in Aceh have a significant impact on profit decrease, firing of SMEs employment, and emerging number of newer SMEs, and therefore roles of social media to market product has great potential to support SMEs, especially in Banda Aceh. Based on results of this research and discussion that have been described previously, conclusions of this research are:

1. The COVID-19 pandemic has reduced product sales of SME actors, thus SMEs have topromote through social media.

2. Use of social media in SMEs can increase sales and the most used social media are Instagram, WhatsApp, and Facebook.

3. Some of SMEs ineffectively used endorsements of Instagram influencers, others revealed that the endorsements had a good impact on SMEs and could increase sales. Endorsment is a public support for a person, a product, or a service with specific purpose .

4. SMEs should have a strategy to cope with the pandemic and should adjust to the conditions. There are several recommended survival strategies to maintain their business, namely: (1) selling through e-commerce because many people are now turning to online shopping, (2) marketing products by utilizing technology to reach out more consumers, (3) improving product and service quality, and (4) conducting customer relationship marketing to create consumer trust and foster customer loyalty.

Referring to the conclusions that have been stated previously, suggestions in this study are as follows: It is also necessary to consider SME owners who have used social media but have not used the paid premium features provided by Facebook and Instagram that are able to target or display advertisements to potential consumers based on age, demographics, and interest on Facebook; It is important for SMEs to formulate STP (segmenting, targeting, and positioning). The existence of STP can help communication or advertising plans for SMEs; Banda Aceh government must increase its concern for SMEs by providing continuous guidance on how to market effectively and efficiently through social media. The government must also be able to encourage all SME sectors, so that SMEs can contribute to regional economic growth; Government is expected to continue to deliver socialization or perform training to SMEs participants. Establishing a network communication for SME participants so that they are able to monitored and their skills will increase; It is necessary to 
form a social media marketer community in Banda Aceh so that SME owners or entrepreneurs can share several ways to promote effectively on social media; SMEs can adopt development and survival strategies that have been described and are expected to be able to adapt to changes in the business environment during this pandemic and in the future. In terms of products, both marketing and sales systems use technology to support business; Future researcher can explore this research and figure out effectiveness of development and survival strategies that have been formulated for SMEs.

\section{References}

Afifuddin. (2010). Introduction to Development Administration. Bandung: CV Alfabeta.

Yasin, F. (2002). Farmers, Small Businesses and Cooperatives with People's Economy Insight. Pekanbaru: Unri Press.

Alyas , M. R. (2017). Strategy for Development of Micro, Small and Medium Enterprises in Strengthening the People's Economy (Case Study on Maros Bread Business in Maros Regency) . Sociohumanities, 19(2),114-120 .

BPS Banda Aceh City. (2019). Banda Aceh in Figures 2019. Banda Aceh: BPS City of Banda Aceh.

Dewi , J. M., John W., and Djaja, W. (2019). Marketing Strategy for Micro, Small and Medium Enterprises (MSMEs) Batik Magenda Tamanan, Bondowoso Regency. Journal of Economic Education: Scientific Journal of Education, Economics, and Social Sciences, 19(1),1907-9990 .

Diskopukmdag. (2018). The Strategic Plan (Renstra) of the Banda Aceh City Cooperatives, SMEs and Trade Office for 2017 - 2022.http://diskopukmdag.ban daacehkota.go.id. Retrieved 19 May 2021.

Edy, S., and Susilo, Y. S. (2011). Strategy for Development of Micro, Small and Medium Enterprises in the Province of the Special Region of Yogyakarta. Journal of Development Economics, 12(1), 45-55.

Hafsah, M. J. (2004). Efforts to Develop Micro, Small and Medium Enterprises (MSMEs) . Infokop Journal. 25(XX).

Hardilawati, W. L. (2019). The Role of Innovation and E-Commerce in Small Business.373.83-87 anita.ac.id/index.php/JAK/article/view/189/136 .

Hendrawan, A., Sucahyowati, H., Cahyandi, K., Indriyani, \& Rayendra, A. (2019). The Influence of Digital Marketing on the Sales Performance of Asti Gauri's MSME Products in Bantasari District, Cilacap. Journal of Administration and Secretarialism, 4(1), 53-60. http://www.jurnal.stiks-tarak .

Kotler, P., and Armstrong, G. (2012). Principles of Marketing. Pearson Education Limited.

Paradise, M. (2021). Analysis of Social Media Marketing Strategy on Micro, Small and Medium Enterprises (MSMEs) in Banda Aceh City. Thesis. Faculty of Economics, University of Muhammadiyah Aceh Banda Aceh 2021 .

Ariani, M. N. U. (2017). Strategic Study of Micro, Small and Medium Enterprises (MSME) Development in Tarakan City. Journal of Organization and Management, 13(2), 99-118

OECD. (2020). SME Policy

Responses. https://read.oecdilibrary.org/view/?ref=119_119680-di6h3qgi4x\&title=COVID-

19_SME_Policy_Responses .

Prabowo, W. A. (2018). The Influence of Digital Marketing on Organizational Performance with Intellectual Capital and Perceived Quality as Intervening Variables in the Three 
Star Hotel Industry in East Java. Journal of Marketing Management, 12(2), 101112. https://doi.org/10.9744/marketing.12.2.101-112.

Quesenberry, K. A. (2019). Social Media Strategy. Kentucky: Rowman \& Littlefield .

Rahman, A. (2009). The role of information technology in increasing the competitiveness of small and medium enterprises, National Seminar, Application of Information Technology 2009 (SNATI 2009) Yogyakarta .

Setyorini, D., Nurhayati, E., \& Rosmita. (2019). The Effect of Online Transactions (eCommerce) on Increasing MSME Profits (Case Study of MSMEs in Iron Processing Ciampea Bogor, West Java). Journal of Management Partners (JMM Online), 3(5), 501-509.

Tambunan, T. (2012). Micro, Small and Medium Enterprises in Indonesia. Important Issues. LP3ES. Jakarta

Hardilawati, W. L. (2020). MSME Survival Strategy amid the COVID-19 Pandemic Journal of Accounting \& Economics, 10(1).

Zulkarnain. (2003). Building People's Economy: Perceptions of People's Economic Empowerment. Yogya-karta:AdicitaKaryaNusa. 